\begin{tabular}{|ccc|}
\hline $\begin{array}{c}\text { JURNAL } \\
\text { INOVASI } \\
\text { TEKNOLOGI } \\
\text { PENDIDIKAN }\end{array}$ & $\begin{array}{c}\text { Jurnal Inovasi Teknologi Pendidikan } \\
\text { Volume 5, No 2, October 2018 (129-139) } \\
\text { Online: http://journal.uny.ac.id/index.php/jitp }\end{array}$ & $\begin{array}{c}\text { Ilkatan Profesi Teknologi } \\
\text { Pendidikan Indonesia }\end{array}$ \\
\hline \hline
\end{tabular}

\title{
PENGEMBANGAN MULTIMEDIA PEMBELAJARAN MATA PELAJARAN TEORI MUSIK KELAS X SMK NEGERI 2 KASIHAN BANTUL
}

\author{
Erni Purwaning Hastuti ${ }^{1}$ *, Sunaryo Soenarto ${ }^{2}$ \\ 1SMK Negeri 2 Kasihan Bantul, 2 Universitas Negeri Yogyakarta \\ 1J1. Bugisan, Jomegatan, Ngestiharjo, Kasihan, Bantul, Yogyakarta 55184, Indonesia \\ 2Jl. Colombo No. 1, Depok, Sleman 55281, Yogyakarta, Indonesia \\ * Corresponding Author. Email: ernipurwaning71@gmail.com
}

\begin{abstract}
Abstrak
Penelitian ini bertujuan untuk: (1) menghasilkan produk multimedia pembelajaran teori musik untuk kelas X SMK Negeri 2 Kasihan Bantul yang berisikan tentang bentuk, nilai nada, dan sukat; (2) mengetahui kelayakan produk multimedia yang dihasilkan, (3) mengungkapkan keefektifan produk multimedia yang dihasilkan. Penelitian ini merupakan penelitian dan pengembangan yang diadaptasi dari model Alessi \& Trollip, yang mencakup tahapan kegiatan sebagai berikut: perencanaan, desain, dan pengembangan. Hasil penelitian ini adalah sebagai berikut (1) produk yang dihasikan adalah multimedia interaktif yang terdiri dari kompetensi, materi, rangkuman, dan evaluasi. (2) Berdasar validasi ahli materi, ahli media dan uji beta, produk multimedia pembelajaran teori musik yang dikembangkan layak digunakan untuk pembelajaran. Kelayakan dapat diperoleh berdasarkan hasil penilaian ahli materi dengan nilai 4,03 (Baik), ahli media dengan nilai 4,32 (Sangat Baik) dan uji beta dengan nilai 4,25 (Sangat Baik). (3) Berdasarkan hasil analisis skor rata-rata $n$-gain dari pretest dan posttest sebesar 0,68 dengan kriteria sedang, maka disimpulkan produk multimedia pembelajaran teori musik kelas $\mathrm{X}$ ini efektif untuk meningkatkan pemahaman siswa tentang materi bentuk, nilai nada, dan sukat.
\end{abstract}

Kata kunci: multimedia pembelajaran teori musik

\section{DEVELOPING TEACHING MULTIMEDIA OF MUSIC THEORY SUBJECT FOR CLASS X OF SMK NEGERI 2 KASIHAN BANTUL. Abstract}

This research aimed: (1) to develop music theory teaching multimedia for class X of SMK Negeri 2 Kasihan Bantul, containing the form, value and time signature; (2) to reveal the feasibility of the developed teaching multimedia; (3) to reveal the effectiveness of the developed teaching multimedia. This research was research and development adapted from Alessi \& Trollip models that covered threephase activities: planning, design, and development. The result was as follows. (1) the product resulted was interactive multimedia that consist of competencies, materials, summary and evaluation. (2) The developed music theory teaching multimedia was advisable to use for teaching according to subject matter experts, media experts, and Beta test. The advisability could be obtained based on the subject matter experts' appraisal score of 4.03 (good), media experts' score of 4.32 (very good) and Beta test score of 4.25 (very good score). (3) Based on the analysis result of the N-Gain mean score from the pretest and posttest 0,68 which fell, in the average criteria, It was concluded that the developed music theory teaching multimedia off class $X$ is effective to elevate students' comprehension on the material of form note value, and time signature.

Keywords: music theory teaching multimedia

Permalink/DOI: http://dx.doi.org/10.21831/jitp.v5i2.15292 


\section{Pendahuluan}

Perkembangan ilmu pengetahuan dan teknologi (IPTEK) telah memberikan dampak yang cukup besar terhadap kehidupan umat manusia di berbagai aspek, tak terkecuali di bidang pendidikan. Berbagai aplikasi teknologi informasi dan komunikasi sudah tersedia dan siap dimanfaatkan secara optimal untuk keperluan pendidikan. Teknologi informasi dan komunikasi memungkinkan terjadinya percepatan transformasi ilmu pengetahuan kepada para peserta didik secara lebih luas (Riana \& Gafur, 2015, p. 213).

Untuk mengikuti perkembangan IPTEK SMK Negeri 2 Kasihan Bantul sebagai sekolah kejuruan telah memiliki peralatan berbasis teknologi untuk menunjang kegiatan pembelajaran, diantaranya: jaringan internet, dua ruang komputer, satu ruang multimedia, dan LCD Proyektor di setiap kelas. Seluruh perangkat tersebut diharapkan dapat digunakan untuk meningkatkan kualitas pembelajaran di sekolah.

Berdasarkan hasil pengamatan terhadap proses pembelajaran teori musik kelas X yang dilakukan di SMKN 2 Kasihan Bantul, diperoleh informasi bahwa, proses pembelajaran yang ada belum sepenuhnya memanfaatkan fasilitas teknologi yang dimiliki sekolah. Disamping itu, metode yang digunakan dalam pembelajaran teori musik lebih dominan menggunakan metode ceramah tanpa dibantu dengan media pembelajaran atau alat peraga pembelajaran lainnya.

Mata pelajaran teori musik, khususnya materi nilai nada dan sukat, merupakan materi dasar untuk memainkan instrumen dan menyanyikan lagu. Untuk dapat menguasai materi tersebut diperlukan pengulangan-pengulangan. Di sisi lain, dengan penggunaan metode ceramah, proses pengulangan dan penguatan materi oleh siswa sangat kurang. Apalagi kondisi siswa SMK Negeri 2 Kasihan memiliki perbedaan kemampuan akademik yang sangat besar. Hal tersebut dapat dilihat dari penerimaan Peserta Didik Baru (PPBD) tahun 2013/2014. Dari jumlah pendaftar sebanyak 198 peserta didik, hanya 78 peserta didik yang memiliki nilai rata-rata diatas 7,00 atau sebesar $40,40 \%$, sementara 120 siswa memiliki nilai dibawah 7,00 atau sebesar $59,60 \%$.

Untuk mengatasi hal tersebut, diperlukan media pembelajaran yang dapat digunakan oleh siswa secara peseorangan dan dpat diulang-ulang. Salah satu media yang mungkin untuk dikembangkan berdasarkan kondisi tersebut adalah multimedia pembelajaran interaktif. Dengan media tersebut siswa dapat mengulang ulang materi yang diajarkan guru diluar jam pelajaran bahkan diluar tatap muka dengan guru.

Hasil penelitian yang dikemukakan oleh Putra \& Ishartiwi (2015, p. 174) menyatakan bahwa penggunaan multimedia pembelajaran mempunyai dampak yang sangat baik terhadap proses dan hasil belajar. Multimedia pembelajaran sangat membantu siswa dalam memahami konsep materi secara konkret (tidak abstrak).

Kehadiran multimedia pembelajaran interaktif dalam proses pembelajaran berbeda, karena materi yang dulunya diajarkan dengan monoton dapat divariasi dengan menampilkan tayangan berupa integrasi teks, suara, gambar bergerak dan video. Hal tersebut tentunya akan membuat siswa lebih tertarik dengan materi yang diajarkan. Dari penjelasan tersebut, maka kehadiran multimedia pembelajaran interaktif merupakan hal yang berguna bagi proses pembelajaran (Siagian \& Lingin, 2012, p. 24).

Berdasarkan latar belakang masalah yang telah diuraikan, maka menarik untuk mengembangkan multimedia pembelajaran mengenai Pembelajaran Teori Musik, khususnya untuk materi nilai nada dan sukat. Rumusan masalah penelitian ini adalah (1) mengembangkan produk multimedia pembelajaran teori musik untuk pembelajaran nilai nada dan sukat yang dihasilkan; (2) kelayakan multimedia pembelajaran teori musik untuk pembelajaran nilai nada dan sukat ditinjau dari aspek materi dan aspek media; (3) efektivitas multimedia pembelajaran teori musik untuk meningkatkan pembelajaran nilai nada dan sukat. Tujuan dari pengembangan ini adalah untuk: (1) 
mengetahui tahap pengembangan produk multimedia pembelajaran teori musik untuk pembelajaran nilai nada dan sukat yang dihasilkan; (2) mengetahui kelayakan multimedia pembelajaran teori musik untuk pembelajaran nilai nada dan sukat; (3) mengetahui efektivitas multimedia pembelajaran teori musik untuk pembelajaran nilai nada dan sukat.

Mayer (2009, p. 1) menjelaskan bahwa multimedia merupakan presentasi materi dengan menggunakan kata-kata dan gambar. Vaughan $(2008$, p. 1) menjelaskan bahwa multimedia adalah kombinasi dari teks, gambar, suara, animasi, dan video yang disampaikan melalui piranti komputer, elektronik atau alat hasil rekayasa lainnya. Purnama $(2013$, p. 4) menjelaskan multimedia sebagai kombinasi dari teks yang dimanipulasi secara digital, foto, seni grafis, suara dan animasi dan elemen video. Munadi $(2013$, p. 57) menjelaskan multimedia adalah media yang melibatkan berbagai indera dalam sebuah proses pembelajaran, termasuk didalamnya segala sesuatu yang memberikan pengalaman secara langsung bisa melalui komputer dan internet atau pengalaman berbuat dan pengalaman terlibat. Malik \& Agarwal (2012, p. 468) memberikan penjelasan bahwa multimedia menyediakan lingkungan belajar konstruktivis berbasis teknologi dimana siswa mampu memecahkan masalah dengan cara eksplorasi, kolaborasi dan partisipasi aktif.

Smaldino, Lowther, \& Russel (2011, pp. 173-174) menyebutkan keuntungan pengguanaan komputer dan multimedia adalah (1) individualisasi pembelajaran, (2) mampu mengakomodasi kebutuhan khusus siswa, (3) mampu memberikan pantauan terhadap hasil belajar siswa, (4) memungkinkan tejadinya manajemen informasi, (5) memberikan pengalaman belajar multisensorik, (6) memerlukan dan meningkatkan partisipasi pembelajar.

Hasil penelitian yang dilakukan Adrianus, Sukmana, Candiasa, \& Kirna (2013, p. 9) menunjukkan bahwa penggunaan media komputer (multimedia) sebagai media dalam pembelajaran dapat memban- tu siswa untuk belajar secara efektif. Temuan penelitian ini juga menunjukkan bahwa motivasi belajar merupakan faktor penting dan kunci bagi keberlangsungan proses pembelajaran termasuk kesiapan untuk menghadapi permasahan yang mungkin muncul dalam proses pembelajaran. Teknologi berbasis komputer mampu memotivasi siswa untuk belajar berbagai mata pelajaran secara efektif, memungkinkan mereka belajar sendiri, siap menghadapi tantangan.

\section{Metode Penelitian}

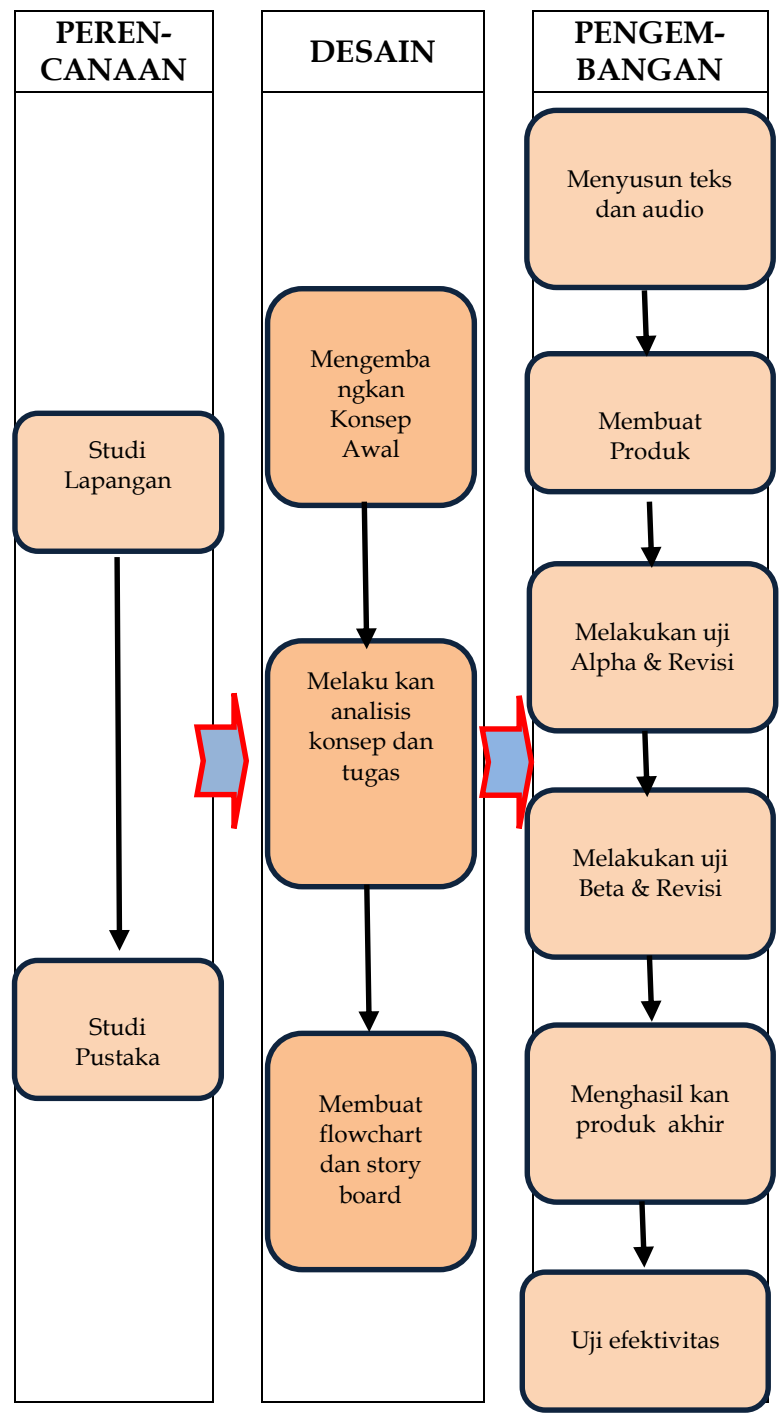

Gambar 1. Langkah pengembangan adaptasi model Alessi \& Trolip

Desain penelitian yang digunakan dalam penelitian ini adalah penelitian dan pengembangan yang diadaptasi dari model Alessi \& Trollip (2001). Adaptasi dari model 
tersebut digunakan karena dipandang tepat untuk digunakan dalam penelitian pengembangan ini dengan mempertimbangkan waktu serta kemudahan penerapannya. Pengembangan multimedia pembelajaran teori musik ini dilakukan dari tahap perencanaan, desain, dan pengembangan, dengan menerapkan uji ahli materi, uji ahli media dan uji efektivitas untuk mengetahui kelayakan multimedia yang dikembangkan. Prosedur tersebut terlihat pada Gambar 1.

\section{Hasil Penelitian dan Pembahasan}

\section{Desain Uji Coba}

Uji coba perlu dilakukan untuk mendapatkan data tentang kualitas media pembelajaran teori musik untuk kelas $X$ SMKN 2 Kasihan. Data dari hasil uji coba dianalisis dan dijadikan sebagai bahan pertimbangan dalam memperbaiki dan menyempurnakan produk.

Tahapan uji coba yang dilakukan adalah Alpha testing yaitu ahli materi dan ahli media masing-masing 2 orang. Ahli media adalah dosen Pendidikan Seni Musik dan Guru Seni Musik SMK N 2 Kasihan, ahli media adalah dosen Program Studi Teknologi Pembelajaran Universtitas Negeri Yogyakarta, sedangkan Beta testing dilakukan oleh 30 siswa kelas X SMK N 2 Kasihan Bantul. Setelah produk multimedia pembelajaran teori musik selesai dibuat dan melalui uji alpha, uji beta dan analisis data, maka dilakukan uji efektivitas. Uji efektivitas dalam penelitian pengembangan ini dilakukan dengan satu kali treatment.

Desain eksperimen yang digunakan adalah before-after (Sugiyono, 2010, p. 415). Model eksperimen tersebut adalah:

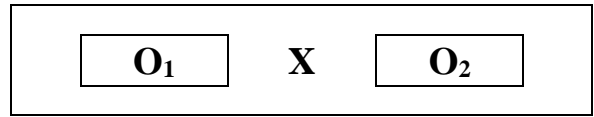

Gambar 2. Desain Eksperimen (BeforeAfter)

Keterangan:

$\mathrm{O}_{1}$ : Pretest

$X$ : treatment (Pembelajaran berbantuan multimedia)

$\mathrm{O}_{2}$ : Posttest
Instrumen pengumpulan data dalam pengembangan ini menggunakan angket dan pedoman penilaian hasil belajar. Kuesioner yang disusun terdiri dari tiga jenis, yaitu: (1) kuesioner untuk ahli materi, yang dipergunakan untuk mengetahui tentang kelayakan materi yang dikembangkan dalam produk multimedia pembelajaran; (2) kuesioner untuk ahi media, yang digunakan untuk mengetahui kelayakan produk multimedia pembelajaran; (3) kuesioner untuk siswa, yang digunakan untuk mengetahui tanggapan siswa terhadap multimedia pembelajaran yang digunakan dalam pembelajaran, meliputi ketertarikan siswa dan kejelasan siswa terhadap materi yang dikembangkan dalam multimedia pembelajaran.

Data yang telah terkumpul kemudian dilakukan skala pengukuran dan pemberian skor. Skala pengukuran yang digunakan dalam penelitian ini adalah skala Likert. Penilaian ini dilakukan untuk mendapatkan tanggapan tentang kualitas produk multimedia pembelajaran yang dikembangkan, yaitu meliputi Sangat Baik (SB) skor 5, Baik (B) skor 4, Cukup skor 3, Kurang $(\mathrm{K})$ skor 2, Sangat Kurang (KB) skor 1.

Setelah skor diperoleh kemudian dikonversikan menjadi data kualitatif skala lima, dengan acuan rumus yang dikutip dari Sukardjo \& Sari (2008, pp. 82-86) sebagai berikut :

Tabel 1. Pedoman Konversi Data

\begin{tabular}{clcc}
\hline Nilai & \multicolumn{1}{c}{ Rumus } & Perhitungan & Kriteria \\
\hline 5 & $\mathrm{X}>\mathrm{Xi}+1,80 \mathrm{Sbi}$ & $\mathrm{X}>4,21$ & $\begin{array}{c}\text { Sangat } \\
\text { baik }\end{array}$ \\
\hline 4 & $\begin{array}{l}\mathrm{Xi}+0,60 \\
\text { Sbi }<\mathrm{X} \leq \mathrm{Xi}+1,80 \text { Sbi }\end{array}$ & $3,40<\mathrm{X} \leq 4,21$ & Baik \\
\hline 3 & $\begin{array}{l}\mathrm{Xi}-0,60 \text { Sbi }<\mathrm{X} \leq \\
\mathrm{Xi}+0,60 \text { Sbi }\end{array}$ & $2,60<\mathrm{X} \leq 3,40$ & Cukup \\
\hline 2 & $\mathrm{Xi}-1,80$ Sbi $<\mathrm{X} \leq \mathrm{Xi}-$ & $1,79<\mathrm{X} \leq 2,60$ & Kurang \\
& 0,60 Sbi & & \\
\hline 1 & $\mathrm{X} \leq \mathrm{Xi}-1,80$ Sbi & $\mathrm{X} \leq 1,79$ & $\begin{array}{c}\text { Sangat } \\
\text { kurang }\end{array}$ \\
\hline
\end{tabular}

Instrumen penilaian hasil belajar berupa soal pre test dan post test yang digunakan untuk memperoleh data tentang hasil belajar di awal dan di akhir pembel- 
ajaran. Hasil pretest dan postest dibandingkan dan dianalisis dengan Gain score serta dibandingkan dengan nilai ketuntasan mata pelajaran teori musik yaitu 75,00. Rata-rata gain yang dinormalisasikan ( $\mathrm{N}$-gain) (Hake, 1999 , p. 3) dinyatakan oleh persamaan berikut ini:

$$
\mathrm{g}=\frac{\mathrm{S} \text { post }-\mathrm{S} \text { pre }}{\mathrm{S} \text { maks }-\mathrm{S} \text { Pre }}
$$

Keterangan:

$$
\begin{array}{ll}
\mathrm{g} & : \text { Gain Score } \\
\mathrm{S} \text { post } & \text { : Rata - rata skor Posttest } \\
\text { S pre } & \text { : Rata - rata skor Prestest } \\
\text { S maks } & \text { : Skor Maksimal }
\end{array}
$$

Nilai yang sudah diperoleh selanjutnya diinterpretasikan dalam tabel klasifikasi gain score (Hake, 1999, p. 3) berikut:

Tabel 2. Klasifikasi nilai Gain

\begin{tabular}{cc}
\hline Nilai & Klasifikasi \\
\hline$(\mathrm{N}$-gain $) \geq 0,7$ & Tinggi \\
$0,7>(\mathrm{N}$-gain $\leq 0,3$ & Sedang \\
$(\mathrm{N}$-gain $) \leq 0,3$ & Rendah \\
\hline
\end{tabular}

Deskripsi perencanaan

Tahap pertama yang dilakukan dalam perencanaan adalah studi pustaka. Kegitan yang dilakukan adalah mengumpulkan materi yang mendukung pengembangan berupa teori tentang pengembangan multimedia pembelajaran dan materi teori musik. Hal ini dilakukan agar produk yang dikembangkan sesuai dengan teori-teori yang sudah dikembangkan oleh para ahli, dan materi teori musik dapat sesuai dengan kebutuhan pengguna. Dengan melakukan studi pustaka, diperoleh berbagai materi dari berbagai sumber yang berbeda untuk meningkatkan dan mengembangan produk multimedia pembelajaran, sehingga diharapkan dapat lebih memperkaya pengetahuan siswa.

Tahap selanjutnya dalam perencanaan adalah studi lapangan. Dalam studi lapangan dapat diketahui : (1) siswa SMKN Negeri 2 Kasihan Bantul memiliki latar belakang dan kemampuan yang beragam, (2) Sumber belajar yang digunakan secara khu- sus untuk mata pelajaran teori musik belum ada, (3) metode pembelajaran yang digunakan dalam proses pembelajaran teori musik adalah metode ceramah, (4) sebagai mata pelajaran dasar-dasar bermain musik, mata pelajaran teori musik berpengaruh pada praktik musik, (5) penggunaan komputer untuk keperluan pembelajaran masih belum optimal, karena belum ada bahan ajar teori musik yang dapat melibatkan penggunaan komputer.

\section{Deskripsi Desain}

Setelah kegiatan perencanaan selesai dilakukan kegiatan selanjutnya adalah mengembangkan ide pembuatan produk multimedia yang sesuai dengan yang diharapkan oleh pengguna. Multimedia tersebut yaitu multimedia pembelajaran teori musik yang dikhususkan pada materi nilai nada dan sukat yang dikembangkan secara menarik dan mudah dipahami. Selanjutnya menyiapkan bahan pembuatan produk. Bahan yang dikumpulkan meliputi Silabus mata pelajaran Teori Musik dan materi nilai nada dan sukat dari berbagai sumber untuk dijadikan acuan dalam pembuatan produk multimedia pembelajaran. Bahan lain yang disipakan selanjutnya adalah Flowchart dan Storyboard sebagai acuan pembuatan multimedia pembelajaran Teori Musik. Hal tersebut dilakukan untuk mempermudah langkah-langkah pengembangan multimedia pembelajaran.

\section{Deskripsi Pengembangan}

Pengembangan produk multimedia pembelajaran secara keseluruhan membahas tentang nilai nada dan sukat, yang terdiri atas petunjuk penggunaan program, kompetensi, materi, rangkuman, evaluasi. Materi dilengkapi dengan animasi dan suara cara memainkan nada, yang diharapkan dapat membantu pengguna dalam membaca notasi musik dengan berbagai bentuk nilai nada.

Pengembangan multimedia pembelajaran teori musik ini menggunakan program Adobe flash CS 6 dan program pen- 
dukung lainnya, yaitu program encore untuk penulisan notasi musik. Proses pembuatan multimedia ini berdasarkan pada rancangan prototype, flowcart dan storyboard yang sudah dibuat sebelumnya sehingga pembuatan dapat berjalan dengan baik.

Berikut beberapa tampilan slide yang ada pada produk yang dikembangkan. Tampilan title page berisi indetitas pengembang, dan judul materi.

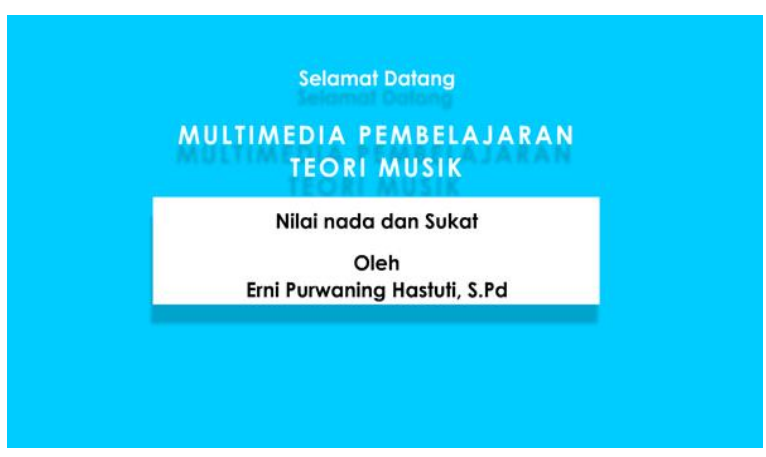

Gambar 3. Tampilan title page

Tampilan layar menu materi teks deskritif berisi petunjuk penggunaan program, kompetensi, materi, rangkuman, evaluasi, profil pengembang dan referensi.

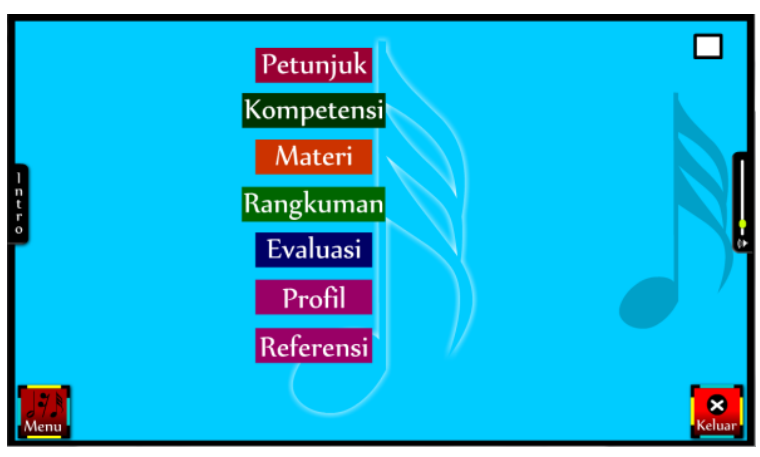

Gambar 4. Tampilan layar menu

Tampilan Materi Berisi Materi

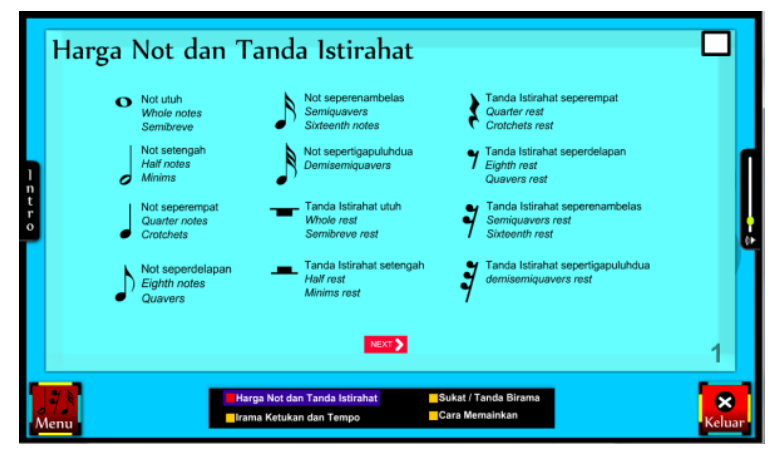

Gambar 5. Tampilan layar Materi

\section{Hasil Uji Coba Produk}

Setelah produk awal multimedia selesai dikembangkan selanjutnya dilakukan uji alpha dan uji beta. Uji alpha dilakukan oleh dua orang ahli materi dan dua orang ahli media. Setelah dilakukan uji alpha kemudian dilakukan beberapa revisi terhadap produk sesuai dengan masukan dari ahli materi dan ahli media.

Validasi materi dilakukan oleh ahli yang menguasai bidang seni musik khususnya teori musik. Validator untuk materi teori musik dalam multimedia pembelajaran ini dilakukan oleh salah satu dosen pendidikan seni musik Universitas Negeri Yogyakarta. Proses validasi dilakukan pada tanggal 5 Juni 2015. Validator materi yang kedua adalah wakil kepala sekolah bidang kurikulum di SMK Negeri 2 Kasihan Bantul. Proses validasi dilakukan pada tanggal 11 Juni 2015. Aspek yang dinilai dari validasi materi adalah aspek pembelajaran dan aspek materi sebagai kelayakan media untuk digunakan dalam pembelajaran.

Penilaian ahli materi terhadap kualitas materi terdiri dari 17 butir penilaian. Dari 17 penilaian terdapat lima aspek dengan kriteria sangat baik (skor lebih dari 4,21) dan 12 aspek dengan kriteria baik ( skor antara 3,40 hingga 4,21). Secara keseluruhan aspek kualitas materi mendapatkan skor 4,06 dengan kategori baik.

Untuk aspek kemanfaatan materi terdiri atas tiga butir penilaian. Dari ketiga aspek penilaian tersebut terdapat satu aspek dengan kriteria sangat baik (skor rerata 4,5 ) dan dua aspek dengan kriteria baik (skor antara 3,40 hingga 4,21). Secara keseluruhan askpek kemanfaatan materi mendapatkan skor 4 dengan kategori baik. Secara rinci rekap hasil rerata skor hasil validasi ahli materi dapat dilihat dalam Tabel 3.

Validasi media dilakukan oleh orang yang menguasai bidang multimedia pembelajaran. Validasi ahli media dilakukan oleh salah satu dosen Program Studi Teknologi Pembelajaran Program Pascasarjana Universitas Negeri Yogyakarta. Proses vali- 
dasi tersebut dilaksanakan pada tanggal 16 Juni 2015. Validator media yang dilakukan oleh salah satu dosen Program Studi Teknologi Pendidikan Fakultas Ilmu Pendidikan Universitas Negeri Yogyakarta. Validasi tersebut dilaksanakan pada tanggal 18 Juni 2018.

Tabel 3. Rekap Rerata Skor Hasil Validasi Ahli Materi

\begin{tabular}{|c|c|c|c|c|c|}
\hline \multirow{3}{*}{ No } & \multirow{3}{*}{ Aspek Penilaian } & \multirow{2}{*}{\multicolumn{2}{|c|}{$\begin{array}{c}\text { Skor Ahli } \\
\text { Materi }\end{array}$}} & \multirow{3}{*}{ Rerata } & \multirow{3}{*}{ Kriteria } \\
\hline & & & & & \\
\hline & & 1 & 2 & & \\
\hline 1 & Kualitas Materi & 3.88 & 4.24 & 4.06 & Baik \\
\hline \multirow[t]{3}{*}{2} & Kemanfaatan Materi & 4.00 & 4.00 & 4.00 & Baik \\
\hline & Jumlah & 7.88 & 8.24 & 8.06 & \\
\hline & Rerata Penilaian & 3.94 & 4.12 & 4.03 & Baik \\
\hline
\end{tabular}

Data hasil penilaian ahli materi dapat dilihat dalam grafik pada Gambar 6 .

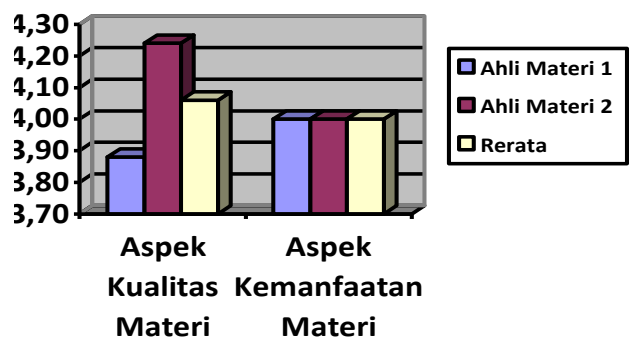

Gambar 6. Hasil validasi ahli materi

Tujuan dari validasi tersebut adalah untuk mengetahui tanggapan validator tentang kualitas media yang akan digunakan untuk pembelajaran. Hasil penilaian dari dua ahli media diperoleh rerata skor nilai 4,25 . Menurut tabel konversi data kuantitatif ke data kualitatif skala lima yang dikutip dari Sukardjo dan Sari (2008, pp. 82-86) tergolong pada kriteria sangat baik.

Aspek desain layar terdiri dari 18 pertanyaan, dan diperoleh nilai rerata 4,5 sebanyak lima aspek, nilai rerata 4,00 sebanyak 11 aspek dan dengan rerata nilai 3,5 sebanyak dua aspek. Dari nilai tersebut diperoleh rerata 4,08 dengan kriteria baik.

Aspek Kemudahan Pengoperasian terdiri dari tujuh pertanyaan, dan diperoleh nilai rerata 4, 5 sebanyak lima aspek dan nilai 4,00 sebanyak dua aspek. Dari tujuh aspek diperoleh nilai rerata 4,36 dengan kriteria sangat baik.

Aspek Keefektifan Navigasi terdiri dari enam pertanyaan, dan diperoleh nilai rerata 4,5 sebanyak lima aspek dan nilai rerata 4,0 sebanyak satu aspek. Dari enam aspek diperoleh nilai rerata 4,42 dengan kriteria sangat baik.

Aspek Kemanfaatan terdiri dari tujuh pertanyaan, dan diperoleh nilai rerata 4,5 sebanyak enam aspek dan nilai rerata 4,0 sebanyak satu aspek. Dari enam aspek diperoleh nilai rerata 4,43 dengan kriteria sangat baik. Secara rinci rekap rerata skor hasil validasi ahli media disajikan pada Tabel 4

Tabel 4. Rekap Rerata Skor Hasil Validasi Ahli Media

\begin{tabular}{llcccl}
\hline \multirow{2}{*}{ No Aspek penilaian } & \multicolumn{2}{c}{$\begin{array}{c}\text { Skor ahli } \\
\text { media }\end{array}$} & $\begin{array}{c}\text { Rata } \\
\text { rata }\end{array}$ & Kriteria \\
\cline { 2 - 4 } & 1 & 2 & & \\
\hline 1 & $\begin{array}{l}\text { Desain Layar } \\
\text { Kemudahan }\end{array}$ & 4.00 & 4.17 & 4.08 & Baik \\
2 & 4.00 & 4.71 & 4.36 & $\begin{array}{l}\text { Sangat } \\
\text { Baik }\end{array}$ \\
$\begin{array}{l}\text { Pengoperasian } \\
3\end{array}$ & $\begin{array}{l}\text { Keefektifan } \\
\text { Navigasi }\end{array}$ & 4.00 & 4.83 & 4.42 & $\begin{array}{l}\text { Sangat } \\
\text { Baik } \\
\text { Sangat }\end{array}$ \\
4 Kemanfaatan & 4.00 & 4.86 & 4.43 & $\begin{array}{l}\text { Sang } \\
\text { Baik }\end{array}$ \\
\hline $\begin{array}{l}\text { Jumlah } \\
\text { Total penilaian }\end{array}$ & 16.00 & 18.57 & 17.29 & \\
Rerata Penilaian & 4 & 4 & 4 & \\
\hline
\end{tabular}

Data hasil penilaian ahli media dapat dilihat dalam grafik pada Gambar 7.

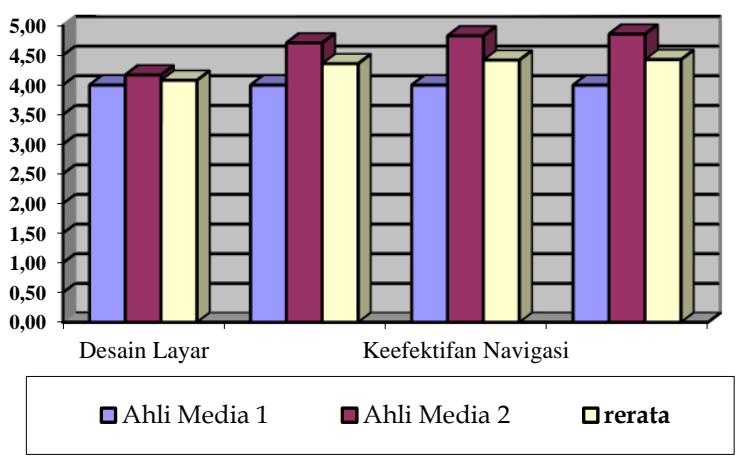

Gambar 7. Hasil validasi ahli media

Uji beta produk multimedia pembelajaran dilaksanakan pada tanggal 3 
Agustus 2015 di ruang ICT SMK Negeri 2 Kasihan Bantul. Uji Beta diikuti oleh 33 siswa. Uji beta dilakukan dengan memberi kesempatan kepada siswa untuk belajar dengan produk multimedia pembelajaran yang dilaksanakan di laboratorium ICT. Setiap siswa diminta memberikan tanggapan tentang produk multimedia pembelajaran melalui angket yang diberikan. Uji coba bertujuan untuk mengetahui tanggapan siswa sebagai pengguna tentang aspek kemudahan produk dioperasikan, kemudahan produk dipelajari isinya, dan aspek kemenarikan tampilan.

Hasil uji beta adalah pada aspek kemudahan pengoperasioan produk diperoleh total skor 142 dengan rerata 4,30 menurut tabel konversi data kuantitatif ke data kualitatif skala lima yang dikutip dari Sukardjo \& Sari (2008, pp. 82-86) tergolong pada kriteria sangat baik. Aspek kemudahan produk dipelajari isinya diperoleh total skor 140 dengan rerata 4,25 tergolong pada kriteria sangat baik. Aspek kemenarikan tampilan diperoleh total skor 141 dengan rerata 4,27 tergolong pada kriteria sangat baik. Dari ketiga aspek diperoleh total nilai rerata 140,97 dengan rerata 4,27 tergolong pada kriteria sangat baik. Data hasil uji Beta dapat dilihat pada Tabel 5.

Tabel 5. Rekap hasil uji Beta

\begin{tabular}{|c|c|c|c|c|}
\hline No. & Unsur Penilaian & $\begin{array}{l}\text { Total } \\
\text { Skor }\end{array}$ & $\begin{array}{l}\text { Rata } \\
\text { Rata }\end{array}$ & Predikat \\
\hline 1 & $\begin{array}{l}\text { Kemudahan } \\
\text { Produk } \\
\text { Dioperasikan }\end{array}$ & 142 & 4.30 & $\begin{array}{l}\text { Sangat } \\
\text { Baik }\end{array}$ \\
\hline 2 & $\begin{array}{l}\text { Kemudahan } \\
\text { Produk } \\
\text { Dipelajari isinya }\end{array}$ & 139.67 & 4.23 & $\begin{array}{l}\text { Sangat } \\
\text { Baik }\end{array}$ \\
\hline \multirow[t]{3}{*}{3} & $\begin{array}{l}\text { Kemenarikan } \\
\text { tampilan }\end{array}$ & 139.69 & 4.23 & $\begin{array}{c}\text { Sangat } \\
\text { Baik }\end{array}$ \\
\hline & Jumlah & 421.15 & 12.76 & \\
\hline & Rerata & 140.38 & 4.25 & $\begin{array}{c}\text { Sangat } \\
\text { Baik }\end{array}$ \\
\hline
\end{tabular}

Data hasil uji beta dapat dilihat dalam grafik pada Gambar 1.

Setelah produk multimedia pembelajaran selesai dilakukan uji alfa dan uji beta, selanjutnya dilakukan revisi berdasarkan masukan dan koreksi yang diperoleh pada uji alpha dan uji beta. Setelah dilakukan revisi kemudian dilaksanakan uji efektivitas yang merupakan uji akhir dari produk multimedia pembelajaran sebelum digunakan untuk pembelajaran. Tujuan dilakukan uji efektifitas adalah untuk mengetahui sejauh mana hasil belajar siswa setelah menggunakan produk multimedia pembelajaran, berapa banyak siswa memperoleh nilai tuntas.

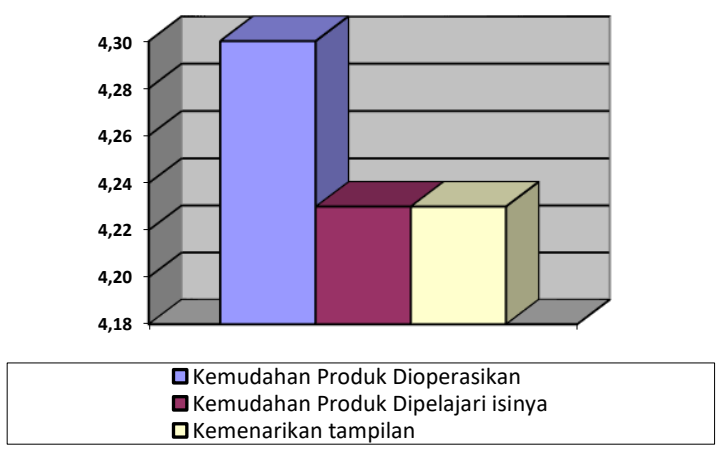

Gambar 8. Hasil uji beta

Untuk mengetahui efektivitas produk multimedia pembelajaran dilakukan dengan membandingkan hasil belajar siswa sebelum menggunakan multimedia pembelajaran yaitu dengan melaksanakan Pretest dan hasil belajar setelah menggunakan multimedia pembelajaran dengan melaksanakan postest.

Uji efektivitas diawali dengan Pretest yang dilaksanakan pada tanggal 1 Agustus 2015. Selanjutnya memberi kesempatan kepada siswa untuk melaksanakan pembelajaran menggunakan produk multimedia pembelajaran teori musik. Kegiatan pembelajaran dengan menggunakan multimedia pembelajaran dilaksanakan pada tanggal 8 dan 11 agustus 2015. Selanjutnya dilaksankan posttest pada tanggal 15 Agustus 2015. Kegiatan pretest, uji coba produk dan posttest dilaksanakan di ruang ICT SMK Negeri 2 Kasihan Bantul, dengan diikuti diikuti oleh 33 siswa. Selanjutnya hasil pretest dan hasil posttest dibandingkan dan ditentukan kriteria sesuai dengan indeks Gain. Adapun hasil dari pretest dan posttest dapat dilihat pada Table 6 . 
Tabel 6. Perbandingan hasil pretes dan posttest

\begin{tabular}{|c|c|c|c|c|c|}
\hline No & Nilai & Pretest & Postest & $\begin{array}{c}\text { Indeks } \\
\text { Gain }\end{array}$ & Kriteria \\
\hline 1 & $\begin{array}{l}\text { Nilai } \\
\text { Maksimal }\end{array}$ & 86.84 & 100.00 & 1.00 & Tinggi \\
\hline 2 & $\begin{array}{l}\text { Nilai } \\
\text { Minimal }\end{array}$ & 7.89 & 44.00 & 0.39 & Sedang \\
\hline 3 & rata rata & 47.45 & 83.31 & 0.68 & Sedang \\
\hline
\end{tabular}

Berdasarkan hasil uji efektivitas yang berupa nilai pretest dan nilai posttest diketahui bahwa terdapat perbedaan antara nilai sebelum dan sesudah menggunakan produk multimedia pembelajaran. Pencapaian kompetensi siswa dapat dilihat dari keberhasilan mencapai ketuntasan minimal (KKM) yaitu 75 .

Perbandingan hasil pretest dan posttest dapat dilihat pada Gambar 9.

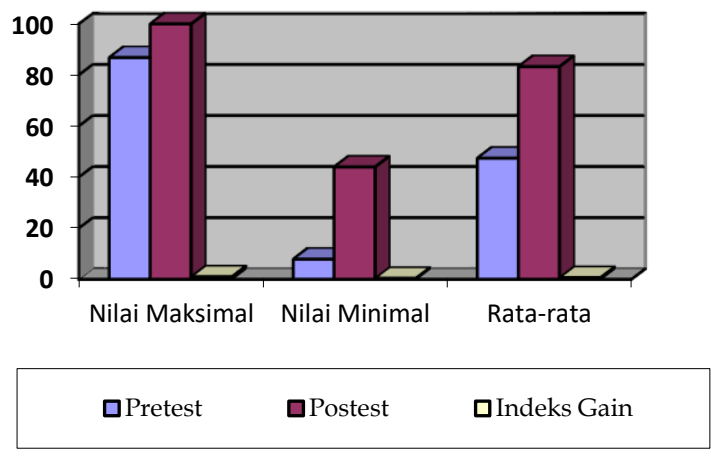

Gambar 9. Hasil Uji Efektivitas

Dari data yang terdapat dalam Gambar 9 dapat dilihat nilai terendah pada pretest adalah 7,89, nilai tertinggi adalah 86,84 dan nilai rata-rata 47,45 . Setelah siswa melaksanakan pembelajaran menggunakan multimedia pembelajaran teori musik dapat diperoleh hasil nilai terendah 44,00, nilai tertinggi 100,00 dengan nilai rata-rata 83,31. Peningkatan nilai pretest dan postes dapat dilihat dari rata-rata N-Gain yaitu 0,68 dengan kriteria sedang. Hasil perubahan nilai dalam N-Gain adalah: (a) 18 siswa mendapatkan nilai $\mathrm{N}$-Gain kategori meningkat tinggi; (b) 15 siswa mendapatkan nilai $\mathrm{N}$ Gain dengan kategori sedang.

Berdasarkan hasil peningkatan dari N-Gain sebesar 0,68 dengan kriteria sedang dapat disimpulkan bahwa penggunaan multimedia pembelajaran teori musik dapat meningkatkan kemampuan belajar siswa.

Selain diketahui adanya peningkatan nilai dari pretes dan posttest dengan N-Gain, dapat dilihat terjadi peningkatan jumlah siswa mendapatkan nilai tuntas. Ketuntasan belajar siswa dapat dilihat pada Table 7 dan Gambar 10.

Tabel 7. Tabel Ketuntasan Siswa

\begin{tabular}{lcc}
\hline \multicolumn{1}{c}{ Jumlah peserta } & Pretest & Postest \\
\hline Jumlah peserta tes & 33 Orang & 33 Orang \\
Jumlah yang tuntas & 4 Orang & 27 Orang \\
Jumlah yang belum tuntas & 29 Orang & 6 Orang \\
\hline
\end{tabular}

Hasil ketuntasan siswa dapat dilihat pada Diagram 10.

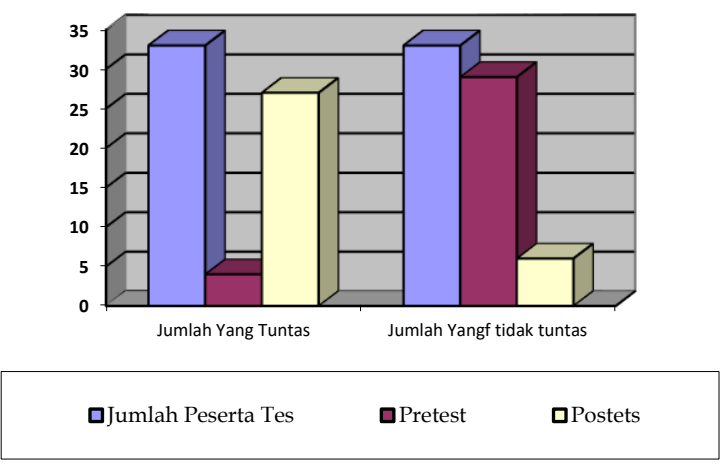

Gambar 10. Diagram Ketuntasan siswa

Berdasarkan Tabel 7 dan Gambar 10 dapat diketahui hasil nilai tes dari 33 siswa pada pretest diperoleh jumlah nilai 1,565 dengan rata-rata nilai 47.45. Dengan nilai tertinggi 86,84 dan nilai terendah 7,89. Peserta yang mendapatkan nilai tuntas 4 siswa dan 19 siswa yang belum tuntas. Dari seluruh siswa 16 siswa mendapatkan nilai diatas rata-rata dan 17 siswa mendapatkan nilai dibawah rata-rata. pada postest diperoleh jumlah nilai 2.749 dengan rata-rata nilai 83,31. Dengan nilai tertinggi 100 dan nilai terendah 44 . Peserta yang mendapatkan nilai tuntas 27 siswa dan 6 siswa yang belum tuntas. Dari seluruh siswa 17 siswa mendapatkan nilai diatas rata-rata dan 15 siswa mendapatkan nilai dibawah rata-rata. Berdasarkan data tersebut diatas dapat di- 
simpulkan bahwa Multimedia Pembelajaran Teori Musik layak digunakan dan dikembangkan di sekolah

\section{Simpulan}

Berdasarkan hasil penelitian pengembangan produk Multimedia Pembelajaran Teori Musik dapat disimpulkan bahwa: Produk yang dikembangkan adalah Multimedia Pembelajaran Teori Musik untuk kelas X SMK Negeri Kasihan Bantul, yang mencakup materi bentuk dan Nilai nada, bentuk dan Nilai Tanda Istirahat dan Sukat. Produk dibuat dengan menggunakan program adobe flash cs 6 yang dilengkapi dengan program penulisan musik yaitu encore. Produk multimedia yang dihasilkan disusun meliputi petunjuk penggunaan, kompetensi, materi, evaluasi, daftar pustaka dan profil pengembang. Produk Multimedia pembelajaran Teori Musik untuk kelas X SMK Negeri Kasihan Bantul dinyatakan layak digunakan.

Kelayakan dapat dilihat dari hasil uji alpha dari dua orang ahli materi, pada aspek kualitas materi mendapatkan skor 4,06 dengan kategori baik. Pada aspek kemanfaatan materi mendapatkan skor empat dengan kategori baik. Secara keseluruhan aspek materi mendapatkan skor 4,03 dengan kategori baik dan hasil penilaian dua orang ahli media. Pada aspek desain layar diperoleh rerata 4,08 dengan kriteria Baik. Pada aspek kemudahan pengoperasian diperoleh nilai rerata 4,36 dengan kriteria sangat baik. Sedangkan, aspek keefektifan navigasi diperoleh nilai rerata 4,42 dengan kriteria sangat baik. Untuk aspek kemanfaatan diperoleh nilai rerata 4,43 dengan kriteria sangat baik. Secara keseluruhan skor rerata penilaian ahli media adalah 4.32 dengan kategori Sangat Baik.

Hasil uji coba pengguna atau uji beta diperoleh hasil untuk aspek kemudahan produk dipelajari isinya diperoleh skor rerata 4,25 dengan kriteria sangat baik. Pada aspek kemenarikan tampilan diperoleh total skor rerata 4,27 tergolong pada kriteria sangat baik. Secara keseluruhan hasil uji coba pengguna mendapatkan skor rerata 4.25 dengan kategori sangat baik.

Produk multimedia pembelajaran ini efektif digunakan sebagai sumber belajar dan dapat digunakan dalam proses pembelajaran diketahui dari hasil uji efektivitas yang dilakukan kepada 33 siswa. Terjadi perbedaan hasil antara pretest dan posttest. Pada pretest diperoleh rata-rata nilai 47.45 , dengan nilai tertinggi 87 dan nilai terendah depalan. Peserta yang mendapatkan nilai tuntas empat siswa dan 19 siswa yang belum tuntas. dibawah rata-rata. Pada postest diperoleh rata-rata nilai 83,31 , dengan nilai tertinggi 100 dan nilai terendah 44. Peserta yang mendapatkan nilai tuntas 27 siswa dan enam siswa yang belum tuntas.

Saran-saran untuk siswa dalam menggunakan multimedia pembelajaran adalah: disarnkan siswa dapat mengulangulang menggunakan produk multimedia teori musik yang dikembangkan, disarankan siswa belajar secara mandiri dan mengembangkan kemampuan membaca nilai nada dan menerapkan sukat. Pengembangan dapat dilakukan dengan mencari sumber lain, mendiskusikan dengan teman atau dengan menanyakan kepada guru teori musik jika menemui materi yang belum dikuasai.

Saran pemanfaatan multimedia pembelajaran Teori Musik bagi guru adalah sebagai berikut: disarankan guru menjelaskan kepada siswa bahwa belajar dengan menggunakan multimedia pembelajaran akan lebih mudah memahami materi, karena siswa dapat mengulang-ulang materi yang dianggap sulit. Selain itu siswa dapat belajar kapan saja dan dimana saja tanpa harus menunggu bertemu dengan guru, artinya siswa dapat belajar secara mandiri, Guru memiliki banyak waktu untuk berdiskusi, karena waktu penyampaian materi telah terbantu dengan multimedia pembelajaran.

Produk multimedia pembelajaran teori musik dapat disebar luaskan kepada seluruh siswa bidang keahlian seni musik klasik sebagai salah satu sumber belajar, yang dapat membantu siswa dalam memahami nilai nada dan sukat. Penyebarlu- 
asan dapat dilakukan dengan meng-copykan file atau CD pembelajaran. Multimedia pembelajaran juga dapat disebarluaskan kepada sekolah lain dan guru lain yang membutuhkan.

\section{Daftar Pustaka}

Adrianus, I. W., Sukmana, I. Y., Candiasa, I. M., \& Kirna, I. M. (2013).

Pengembangan multimedia pembelajaran matematika berpendekatan kontekstual untuk siswa kelas VIII di SMP Negeri 4 Singaraja. E-Journal Program Studi Teknologi Pembelajaran Program Pascasarjana Universitas Pendidikan Ganesha, 3.

Alessi, S. M., \& Trollip, S. P. (2001). Multimedia for learning: methods and development (3rd ed.). Boston: Allyn and Bacon.

Hake, R. R. (1999). Analyzing change/gain scores. Retrieved from http://www.physics.indiana.edu/ s di/AnalyzingChange-Gain.pdf

Malik, S., \& Agarwal, A. (2012). Use of multimedia as a new educational technology tool-a study. International Journal of Information and Education Technology, 5(2), 468-471. https://doi.org/10.7763/IJIET.2012.V 2.181

Mayer, R. E. (2009). Multimedia learning. Yogyakarta: Pustaka Pelajar.

Munadi, Y. (2013). Media pembelajaran. Jakarta: GP Press Group.
Purnama, B. E. (2013). Konsep dasar multimedia. Yogyakarta: Graha Ilmu.

Putra, L. D., \& Ishartiwi, I. (2015). Pengembangan multimedia pembelajaran interaktif mengenal angka dan huruf untuk anak usia dini. Jurnal Inovasi Teknologi Pendidikan, 2(2), 169-178. https:// doi.org/10.21831/tp.v2i2.760 7

Riana, E., \& Gafur, A. (2015). Pengembangan multimedia interaktif pembelajaran Bahasa Inggris materi teks deskriptif untuk siswa SMP/MTs. Jurnal Inovasi Teknologi Pendidikan, 2(2), 212-224. https:// doi.org/10.21831/tp.v2i2.761 1

Siagian, S., \& Lingin. (2012). Pengembangan media pembelajaran interaktif pada mata pelajaran Geografi. Jurnal Teknologi Pendidikan, $5(1)$.

Smaldino, S. E., Lowther, D. L., \& Russel, J. D. (2011). Instructional technology and media for learning (10th ed.). PBoston, MA: Allyn \& Bacon.

Sugiyono. (2010). Metode penelitian pendidikan, Pendekatan kuantitatif, kualitatif dan RED. Bandung: Alfabeta.

Sukardjo, \& Sari, L. P. (2008). Penilaian hasil belajar kimia. Yogyakarta: FMIPA UNY.

Vaughan, T. (2008). Multimedia: making it work (7th ed.). New York: McGrawHil. 